\title{
STRAY GLEANINGS.
}

1. 0.E. clim in Corpus Gl. 427.

This gloss is found on p. 49 of Sweet's Oldest English Texts; in Wright-Wulker col. 12, 1. 14, in Wright II, 103: Caluarium, caluuerclim. The first part of this gloss is evidently an Englishing of the lemma, but the second part is by no means so elear. Sweet mentions the word in his glossary on p. 629. According to him the $i$ is long, and he is therefore most likely of the same view as that propounded by Dieter (Ueber Sprache und Mundart der ältesten englischen Denkmäler der Epinaler und Cambridger Glossen p. 7 note) who suggests that the word should belong to the root of *climan postulated by Ettmuller (395). This view would at first sight seem to be favoured by Wright-Wulker 197.27/28: Caluarium, strictura, uel calverclympe, - especially since this Ms. (Harl. 3376) presents many points of resemblance with the Corpus glossary, - but of this more anon. The difficulty in connecting these two words (viz. -clim and *climan) lies not so much in the form (although we have no certain indication that the $i$ is long) as in the meaning. -

Prof. Gallée of Utrecht has collected some words showing how a consonant, followed by a nasal or liquid presents the somewhat strange phenomenon of sometimes conforming to the rules of the $1^{\text {st }}$ consonantshift, and sometimes on the other hand remaining unshifted. (See: Etudes Archéologiques, Linguistiques et Historiques, dédiées a M. le $D^{\text {r. C. Leeman }}$ p. 279 ff., and ef. Kluge, Beitr. X, 339.) Thus we have Dutch kring by the side of ring (formerly hring) as compared with Greek

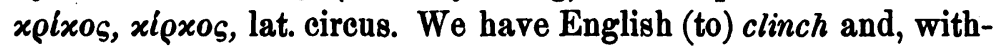
out nasal clickel (see Mayhew and Skeat, M.E. Dict. in voce) by the side of link = an older hlinc. Now there is an O.E. word 
hlinc, meaning, a hill, rising ground. See Bosworth-Toller's interesting quotations. The Links would appear to be the proper name of a hilly part of the country around Edinborough. Link, says Wright (Prov. Dict. in voce) is 'A green or wooded bank on the side of a hill between two pieces of cultivated land'. He also gives a sand-hill as the meaning. See further ib. in voc. linck, linchet, Halliwell in voce and the following quotation from Cassell's Encyclopædic Dictionary: Upon the links, or downs close to them, were seen four or five huts inhabited by fishers (Scott: Antiquary ch. XI).

From what I have quoted from Gallée's article it will be clear that in the Teutonic languages we may expect a form commencing with a $k$ to exist by the side of a form with $h$ (with $h$ is afterwards dropped).

The forms with $c$ are simply legion in the continental dialects, especially in place-names, E. g. Low Saxon klenk, H. G. Klang, 'auf die Klänge' i. e. 'on the sandbanks on the shore' (Gallée p. 280). This will be gathered from an other article of Prof. Gallée's from which, as it will probably be just as little accessible as the foregoing, I take the liberty to produce some extracts. 'By a comparison of these various words and their significations, one sees that to bend is probably the oldest signification; hence we have it in the meaning of to be round, to form a circle, therefore to surround any thing quite and further: 'to surround anything quite or partly, as if by a circle or a curve; out of the signification: to be round, that of to elevate oneself above a level developped itself'. Now, just as well as a bend can curve upwards, it can go downwards; hence by the side of the notion 'elevation' we get that of 'depth' ..... (Nomina Geographica Neerlandica) 1886, p. 85 . Hence we have link etc. in the meaning of valley as well as of hill.

Add to this the significations of wood and rivulet which the word assumes sometimes and we can understand the enormous amount of proper names where the word klink, or kling, figures. See ib. p. 86, where a good many are enumerated.

As to the form with $h$ (see Nom. Geogr. Neerl. p. 87) it exists in Old English as stated before. Now it would be very strange if in Old English only, the two forms did not exist side by side. After what has gone before I need hardly state that I suppose the form *clinc to be hid in the more 
or less mysterious clim for which see supra. Graphically the change is very slight, and the fact of *linc being a rare form may account for its having been misread. The copyist may have thought of the same word which we find in the Harleian glossary (clympe; ef. supra).

Has this hypothetical *clinc, - unlike hlinc - left no traces in Modern English? I dare not be positive but would submit the following quotation to the judgment of others. The change of meaning from wood to that of park is certainly not so great as to arouse suspicion: 'It was common to speak of Paris Garden as the place for these sports, whether the circle in question was in Paris Garden or in the Clink; it being premised that Paris Garden was the King's manor or property of a lord and copyholders, and the Clink was the Bishop of Winchester's manor, and contained or consisted of his park'. (Notes and Queries, June 4. 1887, p. 442).1

\section{Haupt's Zeitschrift IX, 503 b.}

We here find stoicorum glossed by starleornera. The sloici here referred to, whatever the meaning, could certainly not be called: teachers of history. Stoicorum, a more or less legitimate

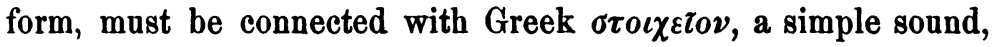
an element as opposed to $\gamma \rho \dot{\alpha} \mu \mu \alpha$, a single letter. Hence we may confidently suppose slarleornera to be corrupted from stafleornera. The difference between $\sigma \tau o \iota \chi \varepsilon \tau o v$ and $\gamma \rho \alpha \mu \mu \alpha$ will not have been perceived by the original glossator. It may have been this very difference that caused the copyist to misunderstand the text before him.

\section{Englische Studien VIII, 474.}

Kluge there published an 0 . E. text from which I copy a few lines:

Swa hwæt swa pu hæfst, hafa to mildheortnysse . pæt pin

1 'This quotation will suffice, I fancy, to establish the meaning of park. Possessors of more provincial glossaries than here at my disposal (Halliwell and Wright where it is not found) will probably be able to supply more instances. Just now (Dec. 89) Dr. Murray's latest comes to hand, in which I find no traces of clink $=$ wood or hill. But of course it may be merely a dialectal word or hid in some more proper names. 
mægen gehelpe pearfan wædlunge and gif pu hwænne gelogodne on nead pearfe ongitst. and gif pu hwæne on wædle be preafodne . and gif $\mathrm{pu}$ hwæne on ænigum pigum aidlodne acnewst. and gif pu hw:ene of prihtene orte geead medne gesihst mid pam gehelpe ne forseoh pu anine. ne forhoga rnine.

It will hardly require any comment if $I$ propose to read the italicised words respectively as follows:

be pearfodne andgitst; pingum (pīgum); $a(=\dot{a})$ hine.

The change of anine to $a$ hine is very slight and the corruption will have crept in through the word anine following directly after.

4. Wright-Wulker p. 100, 1. 44.

We here find herbum glossed by gard (see note), which the latest editor changes to goers. But the form gard=græd, I think, is perfectly legitimate. So far as I am aware gard does not obtain any more but gred, the Mercian representative of graed may be found in the Vespasian Hymns 7.4 (Sweet, O.E. T. p. 409); where Sweet wrongly stars the gloss. See on the word grêd: Modern Language Notes II, 284 (J. M. Hart).

Ghent, May 188?.

H. LOGEMAN. 